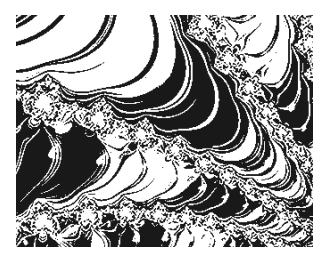

https://doi.org/10.5559/di.29.3.02

\title{
THE IMPACT OF \\ REAL ESTATE MAINTENANCE \\ COSTS ON THE POTENTIAL \\ RESETTLEMENT OF ELDERLY \\ PEOPLE: THE CASE \\ OF SLOVENIA
}

Bojan GRUM

European Faculty of Law, Nova Gorica

Darja KOBAL GRUM

Faculty of Arts, Ljubliana

UDK: 332.872.4-053.9(497.4)

314.15.044-053.6(497.4):332.872.4

Izvorni znanstveni rad

Primlieno: 29. 1. 2019.

The article focuses on the question how maintenance costs impact the potential resettlement of elderly people into suitable accommodation units. In Slovenia, more than 80 percent of households own their own homes, and among these more than 60 percent of owners are over 65 years of age. The main instrument used to measure their opinions was a questionnaire which 471 participants over 65 years of age were asked to complete. The main conclusion is that despite high maintenance costs, Slovenian participants would not sell their property under any circumstances, not even in return for a better-quality living environment. Their attachment to the environment in which they live is extremely high. They prefer to solve problems related to maintaining rather than moving to a more suitable home or environment. We explain this to be due to their strong social affiliation to the micro-environment, strong intergenerational attachment, and the reluctance of Slovenians to migrate.

Keywords: elderly, maintenance costs, resettlement, real estate, demographic characteristics, Slovenia

Darja Kobal Grum, Department of Psychology,

Faculty of Arts, University of Ljubljana, Aškerčeva 2, 1000 Ljubljana, Slovenia.

E-mail: darja.kobal@ff.uni-li.si 
The number of elderly people in Slovenia has been growing. Experts believe that our society is not quite ready for ageing, and that many problems could arise in the process of ageing (Krajnc, 2012). By 2060, the proportion of persons aged at least 80 years and over $(80+)$ will increase from 3.5 percent to 14.1 percent, i.e., from 71,200 to 249,500 inhabitants (SURS, 2017). This will also affect the housing policy. Ageing of the population does not appear to be a process that should be avoided by societies, but as one that should be understood and which requires the adaptation of social institutions and services (Kerbler, 2011). One of the responses of society is the idea that elderly people should be guaranteed the longest possible stay in their home environment, where they would be able to live as freely as possible and with the highest possible quality of living. Active ageing, a society for all ages, and independent living services are concepts that have in recent years been the main themes of research programmes and strategic plans in European countries (Kerbler, 2011). But how are the high costs of maintaining one's own property affected by this?

The vulnerability of elderly people could be associated with a potential lack of financial resources. The 60 percent poverty threshold is linked to the living standard within the respective national context (AGE Platform Europe, 2012). The same source also states that the situation of the elderly in the eastern part of Europe is significantly worse than the situation of the elderly in Western Europe due to varying purchasing power.

With this awareness in mind, our research focuses on Slovenia. More than half of Slovenian households are faced with overpayments related to housing. Some Slovenian households are financially overburdened, and are consequently unable to maintain their own housing, which leads to a decline in housing assets (Ćosić, 2011).

James and Saville-Smith (2015) note that in most of the observed countries, maintenance costs consisting of minor repairs, running costs, and own stock of financial assets are essential for older people. For this reason, researchers recognise the importance of encouraging and assisting the elderly in managing these costs in order to maintain decent living conditions (Bridge \& Flynn 2003; Mullins, Beider, \& Rowlands, 2004). Without this assistance, many elderly people may find themselves in a situation where they will not have the resources to maintain their homes. Unsupported homes lead to poor living conditions, harmful living conditions, and especially among elderly residents, this can result in increased 
DRUŠ. ISTRAŽ. ZAGREB GOD. 29 (2020), BR. 3, STR. 373-393

GRUM, B. KOBAL GRUM, D.: THE IMPACT OF REAL... illness, stress and injuries (Leather, 2000; James \& Saville-Smith, 2015). Elderly persons with low incomes are most susceptible to such conditions. In many observed countries, low income in retirement is sufficient for a normal life. Particularly the countries of Eastern Europe are characterised by small population mobility, deep attachment to real estate, which, also due to its size (children have moved out), represents a major maintenance cost (e.g., heating). A number of studies have pointed out the problem of lower rates of residential mobility in Slovenia (Mandič, 2018; Mandič \& Filipovič Hrast, 2018). A comparison of mobility made in 2000 between young persons and those over 65 years of age showed that only 4 percent of the elderly moved, while the percentage of younger persons who moved in the same period was close to 15.6 percent (Cagney, Browning, Jackson, \& Soller, 2013).

The reason for our research is the fact that more than 80 percent of households in Slovenia own their own homes, and among these more than 60 percent of owners are over 65 years of age (SURS, 2017). The World Health Organization has determined that late adulthood begins after the age of 65 (Majer, 2015), which is why we refer to this age limit in our survey.

\section{"AGEING IN PLACE" AND MAINTENANCE COSTS}

According to literature, we refer to "ageing in place" when an elderly adult is staying in their current dwelling where they feel at home and to which they attach social and emotional meanings (Harper \& Bayer, 2000; Greenwald \& Associates, 2003; Secker, Hill, Villeneau, \& Parkman, 2003; Wylde, 2008; Roy, Bube, Despres, Freitas, \& Legare, 2018). The choice between staying at home and moving to a more supportive home or environment is, for the elderly, in most cases closely linked to a sense of losing autonomy and helplessness (Parry, Vegeris, Hudson, Barnes, \& Taylor, 2004; Burholt \& Windle, 2007; Imamoglu, 2007; Roy et al., 2018). An important attachment of the elderly to the built environment, to the social environment and social infrastructure to which they are accustomed, has been recognised and therefore should be taken into account. That is why we emphasise the importance of adapting dwellings and social infrastructure to elders within their current living environment with which they are familiar and accustomed to. Ramovš (2013) highlights the risk factors at the social and cultural levels: elderly persons becoming weak and dependent, eroding family ties between generations, systems of inheritance and land rights affecting the distribution of power and material goods in the family, migration of young couples leaving their elderly parents to themselves, especial- 
DRUŠ. ISTRAŽ. ZAGREB

GOD. 29 (2020), BR. 3,

STR. 373-393

GRUM, B.,

KOBAL GRUM, D.:

THE IMPACT OF REAL.. ly in societies where young people have traditionally taken care of the elderly, and lack of funds to pay for care.

Living in one's own home has many positive effects that are especially beneficial for the well-being and psycho-physical condition of elderly people. According to Maisel, Gable, and Strachman (2008), studies have shown that independent living promotes successful ageing by improving health, life satisfaction, and increasing the self-esteem of the elderly, which can delay the transition of elderly people to the institutional form of stay.

Elements of the built environment affect walking behaviour, which also affects driving behaviour, and land-use patterns are also important. The environment affects in different ways and is strongly connected to accommodation itself (Grum, 2017). The building environment affects property and vice-versa. If the living environment (neighbourhood) is developed, orderly, clean and well-maintained, it is also expected that each individual residential building be properly maintained, in harmony with the neighbourhood, and compliant with the built environment in which it is located (Grum, 2017). However, the environment usually affects the level of expected (or required) maintenance of the building itself (well-maintained infrastructure usually requires well-maintained accommodation facilities, otherwise the image of the neighbourhood is inconsistent and the welfare of users deteriorates) (Grum, 2017). The relocation of elderly persons is often seen as a traumatic experience (Kerbler, 2012). They do not even want to think about resettlement. This was confirmed by a telephone interview conducted by Sendi, Černič Mali, Jakoš, and Filipovič Hrast (2003), who found that the highest share of those who would relocate is in the age span of 50-55 years (27 percent); this percentage declines with each subsequent age group. The share of elderly persons aged 80 years and over who considered relocation was thus only 8 percent. In general, less than a fifth of elderly people in Slovenia have thought about relocation (18 percent). This is particularly problematic for people who are old. Sendi and others (2003) found that as people age, they are increasingly seeking to have people of the same age in their vicinity. The main problem associated with the elderly living in their own homes is the maintenance costs of the property (including running costs, annual costs - insurance, tax liabilities and the like - and other maintenance costs), especially for those with lower incomes (Sendi et al., 2003). Grum and Temeljotov Salaj (2016) report that one third of the elderly who are between the ages of 54 and 60 spend on average 30 percent of their monthly income to maintain their homes, while those over 85 years of age spend even more than half of their monthly income for this purpose. In addition, elderly people mostly live in older 
DRUŠ. ISTRAŽ. ZAGREB GOD. 29 (2020), BR. 3, STR. 373-393

GRUM, B. KOBAL GRUM, D. THE IMPACT OF REAL... dwellings, which is due to their unwillingness to relocate. Since maintenance costs usually increase rapidly with ageing real estate, the owners of older properties are faced with the risk of rising maintenance costs. Many elderly people, especially those who live alone, just barely cover the current expenses and annual taxes (fee for building land use, property tax), and often do not have sufficient savings to cover other liabilities related to real estate maintenance, which has a negative impact on the value of the property (Grum, 2017).

As previous research has shown, the possibility of "ageing in place" is therefore of central importance for elderly people. Their perception of "ageing in place" is linked to strong feelings of security, social belonging, attachment to home, sense of identity and autonomy. As Wiles, Leibing, Guberman, Reeve, and Allem (2011) noted, in almost all areas, older participants tell us how important the community they live in is to them.

The objective of the present study is to find out how maintenance costs affect the possible relocation of elderly people to suitable housing. Proceeding from this objective, we have made the following hypotheses:

1. In terms of maintenance costs, Slovenian participants expressed statistically significant differences regarding most of their demographic and socio-economic characteristics, but

2. despite high maintenance costs, Slovenian participants would not sell their property under any circumstances, not even in return for a better-quality living environment.

\section{METHODOLOGY AND INSTRUMENTS}

The main instrument used to measure the perceptions of participants was a questionnaire which we compiled for the study on the elderly and the impact of the maintenance costs of their real estate (Grum, 2017). We used the method of review based on the questionnaire (Walonic, 2007). Of the two main types of questions (Keats, 2000), multiple-choice and rank ordering were used. The questionnaire contained 16 variables. The survey was conducted in the period between May 2018 and August 2019. 471 Slovenian participants took part in the survey, which was conducted through personal contact. The participants were recruited using the snowball method. The average survey lasted about 15 to 20 minutes. The Kaiser-Meyer-Olkin (KMO) measure of sampling adequacy is 0.56 , which means that the measured metrics metrically belong together (Fulgosi, 1984). The KMO index ranges from 0 to 1 , which is considered suitable for factor analysis. Bartlett's Test $(\mathrm{BT}=346.378)$, which is statistically significant, shows that the extracted factors can be interpreted (Fulgosi, 1984). A statistical description is shown in Table 1. 


\begin{tabular}{|c|c|c|c|c|c|c|c|}
\hline No. & Variable & Description & $\%$ & No. & Variable & Description & $\%$ \\
\hline \multirow[t]{3}{*}{1} & \multirow[t]{3}{*}{ Gender } & Men & 39.70 & \multirow[t]{6}{*}{9} & \multirow{6}{*}{$\begin{array}{l}\text { Desired type of } \\
\text { dwelling to live }\end{array}$} & With relatives & 34.60 \\
\hline & & Women & 60.30 & & & Home alone & 19.50 \\
\hline & & & & & & Nursing home (a) & 24.80 \\
\hline \multirow[t]{4}{*}{2} & \multirow[t]{4}{*}{ Age } & 65 to 70 years & 33.10 & & & Nursing home (b) & 11.70 \\
\hline & & 70 to 80 years & 38.00 & & & Other & 9.40 \\
\hline & & More than 80 years & 28.90 & & & & \\
\hline & & & & \multirow[t]{3}{*}{10} & \multirow{3}{*}{$\begin{array}{l}\text { Staying at home } \\
\text { of nursing home }\end{array}$} & No & 17.20 \\
\hline \multirow[t]{4}{*}{3} & \multirow[t]{4}{*}{ Location } & In the city & 52.90 & & & Yes & 82.40 \\
\hline & & Village & 33.80 & & & & \\
\hline & & Rural & 13.40 & 11 & Home help & Daily & 17.60 \\
\hline & & & & & & Once a week & 12.10 \\
\hline \multirow[t]{5}{*}{4} & \multirow{5}{*}{$\begin{array}{l}\text { With whom } \\
\text { you live }\end{array}$} & With partner & 42.90 & & & Several times a week & 13.80 \\
\hline & & Relatives & 14.90 & & & Once a month & 8.50 \\
\hline & & Alone & 29.90 & & & No help & 48.00 \\
\hline & & Other & 12.30 & & & & \\
\hline & & & & 12 & Relocation & Certainly not & 29.10 \\
\hline \multirow[t]{4}{*}{5} & \multirow{4}{*}{$\begin{array}{l}\text { Type of } \\
\text { dwelling }\end{array}$} & Apartment & 28.00 & & & No & 25.30 \\
\hline & & House & 45.60 & & & Don't know & 12.10 \\
\hline & & Nursing home & 25.50 & & & Yes & 20.80 \\
\hline & & Other & 0.90 & & & Certainly yes & 12.70 \\
\hline \multirow[t]{6}{*}{6} & \multirow[t]{6}{*}{ Ownership } & Owner & 60.90 & \multirow[t]{3}{*}{13} & \multirow{3}{*}{$\begin{array}{l}\text { Problems with } \\
\text { maintenance cost }\end{array}$} & No & 27.60 \\
\hline & & With relatives & 9.30 & & & Yes & 72.40 \\
\hline & & Market rent & 4.50 & & & & \\
\hline & & Social rent & 4.50 & \multirow[t]{6}{*}{14} & \multirow[t]{3}{*}{ Sale of real estate } & Certainly not & 26.80 \\
\hline & & Other & 20.80 & & & No & 28.00 \\
\hline & & & & & & Don't know & 22.10 \\
\hline \multirow[t]{6}{*}{7} & \multirow[t]{6}{*}{ Satisfaction } & Not & 1.10 & & & Yes & 14.40 \\
\hline & & Not very & 4.50 & & & Certainly yes & 8.70 \\
\hline & & Medium & 5.50 & & & & \\
\hline & & Very & 51.00 & \multirow[t]{3}{*}{15} & \multirow{3}{*}{$\begin{array}{l}\text { Intergenerational } \\
\text { transmission }\end{array}$} & Never & 4.20 \\
\hline & & Very much & 38.00 & & & Don't know & 18.70 \\
\hline & & & & & & No & 44.20 \\
\hline \multirow[t]{5}{*}{8} & \multirow{5}{*}{$\begin{array}{l}\text { Attachment } \\
\text { to the } \\
\text { neighbourhood }\end{array}$} & Not & 2.10 & & & Yes & 32.90 \\
\hline & & Not very & 5.10 & & & & \\
\hline & & Medium & 5.70 & 16 & Financial benefit/ & No & 75.80 \\
\hline & & Very & 36.60 & & Better care & Yes & 24.20 \\
\hline & & Very much & 50.50 & & & & \\
\hline
\end{tabular}

() TABLE 1

Statistical description structure of participants according to demographic, socio-environmental and economic characteristics
The share of elderly people is largest in town centres (52.90 percent), followed by those on the outskirts of towns (33.80 percent). In cities, older people have the choice of several different ways of living - there are several organisations, senior citizens' groups, religious groups, and other civil associations designed to provide support and assistance to the elderly. In rural areas, however, these options are more limited and vary from place to place. Local transport options are less available, and transport costs are higher due to longer distances. There are also fewer rented dwellings, but more owner-occupied dwellings than in the city (Rant, 2013). Elderly people often become more isolated in their neighbour- 
DRUŠ. ISTRAŽ. ZAGREB GOD. 29 (2020), BR. 3, STR. 373-393

GRUM, B. KOBAL GRUM, D. THE IMPACT OF REAL... hoods, more often stay in their own homes, and depend on the help of others (transportation, shopping, etc.) for the provision of services (Grum, 2017).

Most of them live with a partner (42.90 percent) and are aged between 70 and 80 years (38.00 percent). As regards dwelling type, the majority of participants reside in houses, and a relatively large number of them reside in homes for the elderly. Slovenian homes for the elderly are designed for both elderly people with serious health problems who need regular medical care, supervision and care, and for elderly people who are relatively independent. Ramovš concludes (2013) that from the point of view of material supplies in Slovenia, we do not have bad/unsatisfactory/substandard homes for elderly people.

Ultimately, the participants expressed very high satisfaction with their living conditions. As many as 51 percent are satisfied, and 38 percent are even very satisfied. We attribute this to the high degree of home ownership. Many researchers have found a strong correlation between home ownership and self-satisfaction or sense of independence, and loyalty to the neighbourhood (Kleinhans \& Elsing, 2010; Rohe \& Basalo, 1997). It therefore comes as no surprise that the participants expressed extremely high satisfaction with their living environment and a sense of belonging to the neighbourhood.

Most of the participants expressed as their desired type of dwelling to live with relatives (34.60 percent). Kuhar (2012) highlights the small availability of financially affordable housing/small number of financially affordable dwellings as a key reason for extending the desire for intergenerational coexistence in Slovenia, as well as a poorly developed labour market and culturally defined practice, which is linked to the broader factors of a structural or institutional nature, in particular with the availability of state support vis-à-vis family.

Most participants wish to spend their old age at home (relocation - definitely not -29.10 percent; no -25.30 percent). According to Mandič (2009), housing mobility generally has a positive connotation, as higher mobility is supposed to reflect the fact that several households move to a more suitable apartment. In an advanced economy, many households even decide to look for both housing and employment opportunities and choose what gives the best joint combination (Omerren, Rietveld, \& Nijkamp, 2000). However, the statistics for Slovenia show very low housing mobility and, in general, readiness for relocation (SURS, 2017). Strong attachment to home, location and neighbourhood is also reflected in the fact that elderly persons are not willing to sell their property. 
DRUŠ. ISTRAŽ. ZAGREB

GOD. 29 (2020), BR. 3, STR. 373-393

GRUM, B. KOBAL GRUM, D.: THE IMPACT OF REAL..
With respect to running maintenance, more than 72.40 percent of participants confirm that they do have problems with running costs or maintenance. Interestingly, however, 44.20 percent of them have not yet transferred the ownership of their property to relatives, with more than 75.80 percent expressing the opinion that their relatives would not take better care of them if they had any financial benefit. A study by Bernheim, Shleifer, and Summers (1985) has shown that children visit and call their parents more often if they own a large property that will once be the subject of heritage. This conclusion is confirmed by the exchange motive, where inheritance is granted to children in exchange for their previous attention and care. Parents can exercise control over the help and attention of their child and, in the event of insufficient attention or lack of care, endanger them in this way in order to allocate wealth to the benefit of other children (Bernheim et al., 1985). On the other hand, Habjanič and Lahe (2012) note, in the case of Slovenia, that among the elderly population living in the home environment, 81.60 percent of respondents reported that they are the victims of economic violence, which takes the following forms: ban on managing their own money, taking their money and pensions, compulsory conclusion of a contract for the transfer of property, forgery of signature on a contract, and change of testament in favour of others, which can explain our results.

\section{RESULTS AND DISCUSSION}

An analysis of variance was conducted to test the results. The data were analysed with respect to the participants' maintenance problems (see Table 2).

Statistically significant differences regarding the participants' maintenance problems are shown by their age, the location of their residence, who they live with, the type of dwelling they live in, ownership, satisfaction with their dwelling, desired type of dwelling for living, issues of whether to stay at home or move to an old-age home, intergenerational transmission and, consequently, financial benefits. The results are shown in Table 2.

It is interesting that the participants do not show statistically significant differences regarding maintenance costs by gender, attachment to the home, and readiness to move or even sell their property. Due to the potentially lower mobility of the elderly, the age-related influence on migration is greatly enhanced. Elderly people are less likely to opt for migration. This, however, does not necessarily mean that there is less migration in such populations, because the indirect impact of an ageing population on migration can occur (Malačič, 2008). The lack of young people in such populations simply 
DRUŠ. ISTRAŽ. ZAGREB GOD. 29 (2020), BR. 3, STR. 373-393

GRUM, B. KOBAL GRUM, D. THE IMPACT OF REAL...

(1) TABLE 2

The results of the analysis of variance regarding maintenance problems according to affiliation to different demographic, socio-economic and economic factors attracts young immigrants from elsewhere. Results show that in old populations, inheritance increases with age. Our conclusion is that the participants would not sell their property under any circumstances, not even in return for a better-quality living environment. Their attachment to the environment in which they live is extremely high and does not vary according to running costs/maintenance. They prefer to solve the problems of maintaining rather than moving to a more suitable home or environment. We explain this to be due to their strong social affiliation to the micro-environment, strong intergenerational attachment, and the reluctance of Slovenians to migrate. In this regard, social support networks play an important role, since they help the elderly in their everyday life tasks. They can offer both financial and material assistance, as well as emotional support, and enable social integration of the elderly into society.

\begin{tabular}{lrrrrc}
\hline Variable & $\begin{array}{r}\text { Sum } \\
\text { of Squares }\end{array}$ & df & $\begin{array}{r}\text { Mean } \\
\text { Square }\end{array}$ & $F$ & Sig. \\
\hline Gender & 0.747 & 1 & 0.747 & 3.129 & 0.078 \\
Age & 4.456 & 1 & 4.456 & 7.290 & $0.007^{*}$ \\
Location & 5.787 & 1 & 5.787 & 11.660 & $0.001^{*}$ \\
With whom you live & 8.438 & 1 & 8.438 & 7.065 & $0.008^{*}$ \\
Type of dwelling & 3.509 & 1 & 3.509 & 6.106 & $0.014^{*}$ \\
Ownership & 21.823 & 1 & 21.823 & 8.242 & $0.004^{*}$ \\
Satisfaction & 3.635 & 1 & 3.635 & 5.485 & $0.020^{*}$ \\
Attachment to the neighbourhood & 1.002 & 1 & 1.002 & 1.139 & 0.286 \\
Desired type of stay & 14.469 & 1 & 14.469 & 8.483 & $0.004^{*}$ \\
Stay at home/not in nursing home & 0.775 & 1 & 0.775 & 4.985 & $0.026^{*}$ \\
Home help & 9.088 & 1 & 9.088 & 3.642 & 0.057 \\
Relocation & 5.154 & 1 & 5.154 & 2.570 & 0.110 \\
Sale of real estate & 4.503 & 1 & 4.503 & 2.826 & 0.093 \\
Intergenerational transmission & 6.353 & 1 & 6.353 & 9.456 & $0.002^{*}$ \\
Financial benefit & 1.482 & 1 & 1.482 & 8.045 & $0.005^{*}$ \\
\hline
\end{tabular}

*Difference is statistically significant $(p<0.05)$

The most important source of social support to elderly individuals is their family members (partner, children - usually daughters, and others). The results point to another important source of social support, namely, neighbourhood ties. These are extremely important for individuals who remain independent, that is, who are not institutionalised, nor are they living with any family members. A more detailed analysis of the networks of elderly people in Slovenia (Hlebec, 2009) reveals that one network stands out - one in which there is great emphasis on neighbourhood support, i.e., a network integrated into the living environment. Table 3 shows correlations. 
DRUŠ. ISTRAŽ. ZAGREB

GOD. 29 (2020), BR. 3,

STR. 373-393

GRUM, B.

KOBAL GRUM, D.

THE IMPACT OF REAL...

TABLE 3

(Pearson) correlation between factors

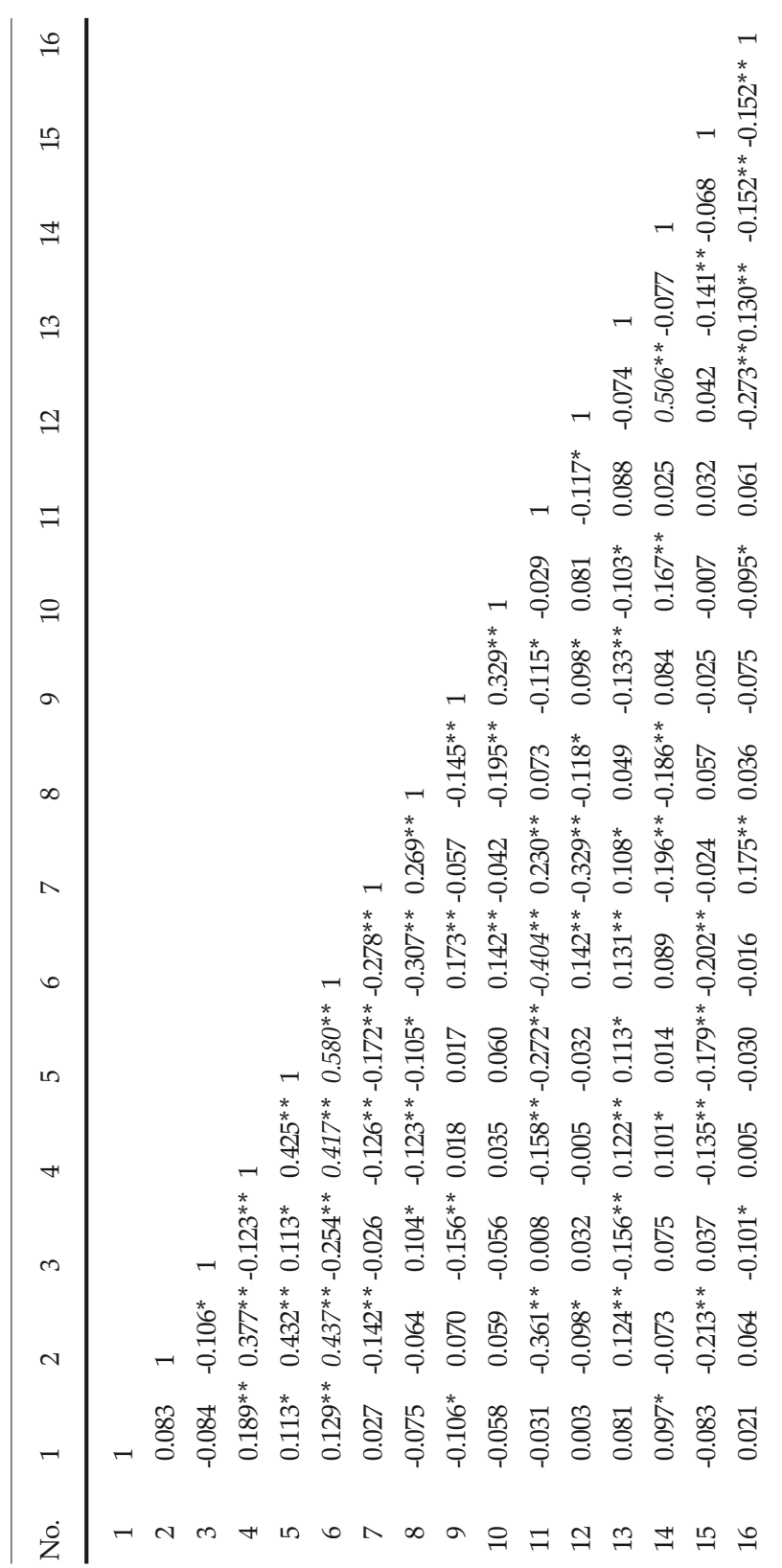

ชิ ఫิ $-\frac{d}{d} d$

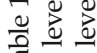
元 ษᄈ 毒吉志 है है है

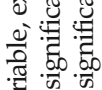
त. 0 동 ฮี ปै छ 00 之े

A direct relationship is shown between ownership and age $(0.437)$, which confirms our starting point indicating that the degree of ownership increases with the age of participants. There is a correlation also between ownership and variables with whom a participant lives (0.417) and the location where they live (0.580). Most of the participants live with a partner 
DRUŠ. ISTRAŽ. ZAGREB GOD. 29 (2020), BR. 3, STR. 373-393

GRUM, B. KOBAL GRUM, D.: THE IMPACT OF REAL... lings are considered as individual houses (SURS, 2017). Another correlation is shown between ownership and home care $(-0.404)$, which could indicate that participants who still live in their own homes are relatively healthy and need little or no home care. A positive correlation exists between the will to sell real estate and the will to relocate (0.506), which is also confirmed by our research. Most participants want to spend their old age at home (relocation - definitely not 29.10 percent; no 25.30 percent) (see Table 1 ).

Last but not least, there are many advantages to ageing in one's own place. Economically, providing help with home maintenance or home care is dramatically less expensive than institutional care (Canadian Institute for Health Information, 2011). Moreover, the social and health advantages of ageing at home have been extensively documented (Cutchin, 2003; Kerbler, 2011; Roy et al., 2018) and include attachment to place, familiarity with the neighbourhood, and ability to maintain functional health.

There is evidence to suggest that home modifications can reduce or even eliminate care in the home (Home Adaptations Consortium, 2010; Liu \& Lapane, 2009; Verbrugge \& Sevak, 2002), and reduce the likelihood of entering residential care (Newman, Struyk, Wright, \& Rice, 1990).

Table 2 shows the detailed differences in the average level of agreement between factors, where statistically significant differences in terms of property maintenance are expressed.

The overall picture is evident from the graph (Figure 1), which shows average agreement levels regarding problems related to property maintenance costs.

The figure shows that the lowest levels of agreement with regard to maintenance costs are reflected by elderly persons aged 80 years (1.1765) who live in cities (1.2008), or nursing homes (1.1083), either in commercially rented dwellings (1.1429), or in a common household with relatives (1.963).

On the other hand, the graph shows that the highest levels of agreement with regard to maintenance costs are reflected by the elderly living in social rent dwellings (1.5238), by those who express medium satisfaction with their current housing situation (1.6154), and by those who have not yet decided on the intergenerational transfer of title to their property (1.4318).

Statistically significant differences with respect to maintenance costs are shown in terms of age, location, who participants live with, type of dwelling, ownership, satisfaction, desired type of stay, intergenerational transfer and, consequently, financial benefits. 


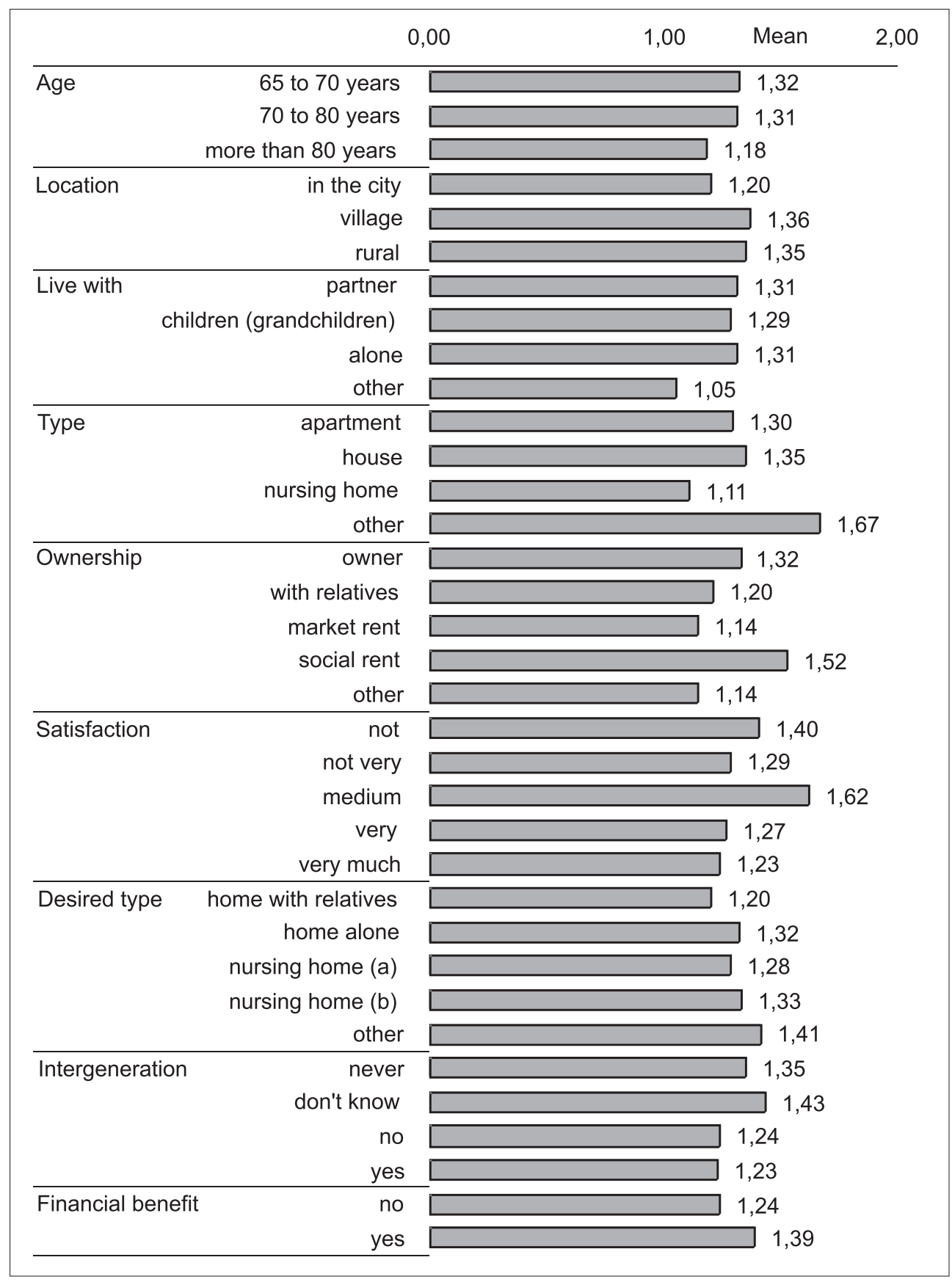

(1) FIGURE 1

Average agreement levels in relation to problems related to the maintaining costs of the property
Surprisingly, a comparison reveals that the participants' level of problems with maintenance costs decreases with higher age (the average accordance level of 65 to 70 years old is 1.3205 , that of over 80 years old is 1.1765). This indicates a possible social orientation of Slovenia - care for older people 
DRUŠ. ISTRAŽ. ZAGREB GOD. 29 (2020), BR. 3, STR. 373-393

GRUM, B. KOBAL GRUM, D. THE IMPACT OF REAL... either by the neighbourhood (neighbours) or mostly by relatives. The probability of an intergenerational transfer of real estate ownership is increasing, and also of transferring the concern over maintenance costs. A survey on social networks in Slovenia (Ferligoj \& Novak, 2002) has found that neighbours are important in giving more material support, as in this case they account for almost 17 percent of the social support network. On the other hand, Dremelj (2003) concludes that neighbours do not seem to be very important in providing other types of support, where they do not exceed 10 percent. Particularly negligible is their percentage in the network of financial and emotional support (Dremelj, 2003), which confirms our assumption that relatives are nevertheless those who, at a high age, assume the burden of real estate maintenance.

A comparison shows that the participants' level of problems with maintenance costs is lower in those who live in urban centres (average degree of agreement 1.2008), while participants who live in nursing homes expressed the lowest level of maintenance cost problems (average degree of agreement 1.1083). Those who expressed a high level of satisfaction with their living conditions also expressed the lowest level of maintenance cost problems (average degree of agreement 1.2346). Research shows that the elderly want to stay in their homes in the same known environment for as long as possible, as well as to maintain their independence and autonomy for as long as possible. However, there is a problem with maintaining one's own real estate. Trček (2005) establishes that the factor most closely related to investing in real estate is monthly household income. He notes that this factor mainly depends on a participant's education and the size of their household (Trček, 2005). Furthermore, Uršič (2005) concludes that migration activity is also significantly influenced by housing status and the number of persons in the household (Uršič, 2005). The lower degree of agreement regarding maintenance in urban centres can be explained by the higher education level of elderly people, who are more educated and thus financially stronger, and live in more suitable (smaller) dwellings (multi-apartment buildings) (Boge, Temeljotov Salaj, Bjørberg, \& Larssen, 2018). Houses are often too large, difficult to access and expensive to maintain, inadequate, in difficult-to-access locations, and with municipal costs rising year on year, etc. (Žmahar, 2013). And not surprisingly, those participants who did make the intergenerational transfer reported a lower level of maintenance cost problems (average degree of agreement 1.2257) in comparison to those who still owned real estate. 
DRUŠ. ISTRAŽ. ZAGREB GOD. 29 (2020), BR. 3, STR. 373-393

GRUM, B. KOBAL GRUM, D.: THE IMPACT OF REAL...
The results related to ownership show that elderly persons who live in social rent dwellings expressed a higher level of agreement regarding maintenance costs (1.5238). We attribute this to poverty. Mandič and others (2006) estimate that 28 percent of households in Slovenia have inadequate housing conditions. The usual comparable indicator of residential area shows that, according to a survey, the average apartment area per person is $32.98 \mathrm{~m}^{2}$, which comes to 1.19 rooms. The survey reveals that 39 percent of households have less than one room per person, which in European housing statistics is classified as overpopulation. The survey also revealed other important factors, such as excessive operating costs, defective or worn-out installations, and lack of infrastructure (Mandič et al., 2006).

In Slovenia, more than 80 percent of elderly people own or purchase their own dwellings (SURS, 2017). Rohe and Stewart (1996) estimated that the satisfaction level among apartment owners is higher than among tenants. Not surprisingly, the results indicate that those who express higher satisfaction with their dwelling express a lower level of agreement regarding maintenance costs.

According to the results, the participants would not sell their property under any circumstances, not even in return for a better-quality living environment. They prefer to solve the problems of maintenance rather than moving to a more suitable home or environment. The result of resource HOP 016 (2017) presents the reasons for older persons moving out of their homes, and interestingly, only 24 percent of all respondents stated that the main reason for their relocation was the high cost of maintaining the property. Other respondents attributed their relocation to family reasons, intergenerational real estate transfers, and advance migration planning.

Hansson and Lundgren (2018) have found that in many other European countries, particularly low-income households and households that live in large homes (too big houses, apartments, farms) are among those who decide to move out of their homes because of maintenance costs that are too high.

\section{CONCLUSION}

The paper focuses on the question how the maintenance costs of real estate owned or occupied by the elderly impact their satisfaction, quality of living and potential relocation to a suitable accommodation unit. In Slovenia, more than 80 percent of households own their own homes, and among these more than 60 percent of owners are over 65 years of age. The main instrument for measuring the participants' expectations was a questionnaire in which 471 participants aged over 65 took 
DRUŠ. ISTRAŽ. ZAGREB GOD. 29 (2020), BR. 3, STR. 373-393

GRUM, B. KOBAL GRUM, D. THE IMPACT OF REAL... part. We conducted an analysis of variance in order to test the differences between the participants' demographic and socio-economic characteristics in connection with maintenance cost problems.

The ageing process of the population and the associated problems of ensuring the sustainability of health, social and housing care for elderly people are becoming an increasing challenge for developed countries, including Slovenia. New strategies of caring for the ageing population are therefore being increasingly directed towards the shifting of supply activities to the home environment, and thus to extending older people's living at home, which is also in line with the aspirations and wishes of the elderly. They mostly wish to stay for as long as possible in their homes, in the same living and social environments. Elders want to live in an environment where they will feel well, where they can be integrated into society, learn about culture, and enjoy life in the community with their neighbours. The results of our statistical analyses confirm our first hypothesis and evidently show that in terms of maintenance costs, Slovenian participants expressed statistically significant differences regarding most of their demographic and socio-economic characteristics. The results clearly show that the lowest level of agreement towards maintenance costs is reflected by persons aged 80 years and over, who live in cities or nursing homes, in commercially rented dwellings or in a common household with relatives. On the other hand, the highest level of agreement towards maintenance costs is reflected by the elderly living in social rent dwellings and by those who express medium satisfaction with their current housing situation, and have not yet decided on the intergenerational transfer of title to their property. The study confirmed the second hypothesis. Hence, our main conclusion is that the participants would not sell their property under any circumstances, not even in return for a better-quality living environment. Their attachment to the environment they live in is extremely high. They prefer to solve the problems of maintenance rather than moving to a more suitable home or environment. We explain this to be due to their strong social affiliation to the micro-environment, strong intergenerational attachment, and the reluctance of Slovenians to migrate. Therefore, understanding the dynamic of older adults in their residential neighbourhoods is important for social policy and public health programmes in an ageing Slovenia. Maintaining independence is recognised as an underpinning feature of successful ageing in place. Also, Bridge, Phibbs, Kendig, Mathews, and Bartlett (2006) have found that improvements in residential housing options can substantially increase opportunities for healthy and productive ageing 
DRUŠ. ISTRAŽ. ZAGREB GOD. 29 (2020), BR. 3, STR. 373-393

GRUM, B. KOBAL GRUM, D.: THE IMPACT OF REAL... by providing a supportive physical environment for older people and housing assistance packages that increase physical and social independence and enable effective care without relocation. Older people deserve special consideration in government policy, community support and industry response, but they are often a low priority for resource allocation or policy innovation because of their relative lack of economic and political power.

The results of our research are important for alerting key actors in society, housing policy planners, social workers, housing organisations, health care organisations and others that it is imperative to address the housing problems of elderly persons in the context of their needs, desires, wishes and expectations. Similar conclusions have been made by other authors in their studies (Roy et al., 2018).

The conclusions of our research are also intended to be used as recommendations for the national advisory service in considering the best and most effective ways of collecting the necessary data on the problems and needs of elderly people within the known environment, and the organisations that can quickly and effectively offer appropriate solutions. Deferring housing problems into the future will only aggravate the problem of rising costs of maintaining unsustainable housing.

\section{ACKNOWLEDGEMENTS}

The research reported in this paper was made possible through the financial support by the Slovenian Research Agency (Development of social infrastructure and services for community based long-term care J6-9396; Psychological and neuroscientific aspects of cognition, P5-0110.

\section{REFERENCES}

AGE Platform Europe (2012). Older people also suffer because of the crises. Available at http://www.age-platform.eu/publication-type/agepublications

Bernheim, B. D., Shleifer, A., \& Summers, L. H. (1985). The strategic request motive. Journal of Political Economy, 93(6), 1045-1075. https://doi. org/10.1086/261351

Boge, K., Temeljotov Salaj, A., Bjørberg, S., \& Larssen, A. K. (2018). Failing to plan - planning to fail: How early phase planning can improve buildings' lifetime value creation. Facilities, 36(1/2), 49-75. https:// doi.org/10.1108/F-03-2017-0039

Bridge, C., \& Flynn, M. (2003). Home maintenance and modification information needs and evidence based practice solutions in NSW. Joint paper presented at National housing conference, Adelaide, Nov 2003.

Bridge, C., Phibbs, P., Kendig, H., Mathews M., \& Bartlett, H. (2006). The costs and benefits of using private housing as the home base for care for 
DRUŠ. ISTRAŽ. ZAGREB GOD. 29 (2020), BR. 3, STR. 373-393

GRUM, B. KOBAL GRUM, D.: THE IMPACT OF REAL... older people: A systematic literature review. Australian Housing and Urban Research Institute. Available at https://www.ahuri.edu.au/ data/assets/pdf_file/0013/2821/AHURI_Positioning_Paper_No94_Cost_ Benefits_for_Older_People.pdf

Burholt, V., \& Windle, G. (2007). Retaining independence and autonomy: Older people's preferences for specialised housing. Research Policy and Planning, 25(1), 13-26.

Cagney, K. A., Browning, C. R., Jackson, A. L., \& Soller, B. (2013). Networks, neighborhoods, and institutions: An integrated "Activity space" approach for research on aging. Washington (DC): National Academy of Sciences. Available at https://www.ncbi.nlm.nih.gov/books/NBK184369/

Canadian Institute for Health Information (2011). Health care in Canada: A focus on seniors and aging. Ottawa. Available at https://secure. cihi.ca/free_products/HCIC_2011_seniors_report_en.pdf

Cutchin, M. P. (2003). The process of mediated ageing-in place: A theoretically and empirically based model. Social Science and Medicine, 57(6), 1077-1090. https://doi.org/10.1016/S0277-9536(02)00486-0

Ćosić, N. (2011). Lastniško stanovanje kot pomemben dejavnik varnosti starejših ljudi. (Proprietary housing as an important factor for the safety of older people). Ljubljana: Fakulteta za družbene vede.

Dremelj, P. (2003). Sorodstvene vezi kot vir socialne opore posameznikov (Kinship ties as a source of social support for individuals). Družbene razprave, 19(43), 149-170.

Ferligoj, A., \& Novak, M. (2002). Omrežja socialnih opor prebivalstva Slovenije (Networks of social support of the population of Slovenia). Ljubljana: Fakulteta za družbene vede in Inštitut Republike Slovenije za socialno varstvo.

Fulgosi, A. (1984). Faktorska analiza (Factor analysis). Zagreb: Sveučilište u Zagrebu, Filozofski fakultet u Zagrebu.

Greenwald, M., \& Associates, I. (2003). These four walls... Americans 45+ talk about home and community. Available at http://assets.aarp.org/rgcen ter/il/four_walls.pdf

Grum, B. (2017). Impact of facilities maintenance on user satisfaction. Facilities, 35(7-8), 405-421. https://doi.org/10.1108/F-03-2016-0034

Grum, B., \& Temeljotov Salaj, A. (2016). Medgeneracijsko sobivanje mladih in starih: medkulturna primerjava (Intergenerational coexistence of young and old: An intercultural comparison). Urbani izziv, 27(1), 76-88. https://doi.org/10.5379/urbani-izziv-2016-27-01-006

Habjanič, A., \& Lahe, D. (2012). Nasilje nad starejšimi slabega zdravja v domačem okolju in domovih starejših občanov (Violence against the elderly of poor health in the home environment and homes of the elderly). Obzornik zdravstvene nege, 46(1), 37-45.

Hanson, A. G., \& Lundgren, B. (2018). Defining social housing: A discussion on the suitable criteria. Housing, Theory and Society, 36(2), 149-166. https://doi.org/10.1080/14036096.2018.1459826

Harper, L., \& Bayer, A. H. (2000). Fixing to stay: A national survey of housing and home modification issues. Washington, DC: AARP. 
DRUŠ. ISTRAŽ. ZAGREB GOD. 29 (2020), BR. 3, STR. 373-393

GRUM, B., KOBAL GRUM, D.: THE IMPACT OF REAL..
Hlebec, V. (2009). Oskrba starih med državo in družino: oskrba na domu (Care for the elderly between the state and the family: Home care). Teorija in praksa, 4(47), 765-785.

Home Adaptations Consortium (2010). Home adaptations for disabled people. Equality and excellence in future provision. Addressing the nine key comprehensive spending. Review Questions posed by HM Treasury. Care and repair England. Available at https://www.cotss-housing.co.uk

HOP 016 (2017). Written evidence submitted by United for All Ages [HOP 016]. Available at http://data.parliament.uk/writtenevidence/ committeeevidence.svc/evidencedocument/communities-and-localgovernment-committee/housing-for-older-people/written/49204.pdf

Imamoglu, C. (2007). Assisted living as a new place schema. A comparison with homes and nursing homes. Environment and Behavior, 39(2), 246-268. https://doi.org/10.1177/0013916506289977

James, B., \& Saville-Smith, K. (2015). Older people's home repair and maintenance: Ageing well in place in New Zealand. ENHR 2010, 4-7 July, Istanbul, 22nd International Housing Research Conference.

Keats, D. M. (2000). Interviewing, a practical guide for students and professionals. Buckingham: Open University Press.

Kerbler, B. (2011). Prilagajanje grajenega bivalnega okolja za potrebe starejših ljudi (Adapting the built living environment for the needs of older people). Geodetski vestnik, 55(1), 57-69. https://doi.org/10.15292/ geodetski-vestnik.2011.01.057-069

Kerbler, B. (2012). Stanovanjsko varstvo starejšega prebivalstva v Sloveniji: domovi za starejše in lastniško zasedena stanovanja (Housing protection of the elderly population in Slovenia: Homes for the elderly and owner-occupied dwellings). Revija za geografijo Journal for Geography, 7(1), 101-114.

Kleinhans, R., \& Elsinga, M. (2010). Buy your home and feel in control: Does home ownership achieve the empowerment of former tenants of social housing? International Journal of Housing Policy, 10(1), 41-61. https://doi.org/10.1080/14616710903573757

Krajnc, A. (2012). Older adults as a special learner audience. Andragoška spoznanja, 18(3), 25-37. https://doi.org/10.4312/as.18.3.25-37

Kuhar, M. (2012). Podaljšano sobivanje staršev in mladih odraslih (Prolonged coexistence of parents and young adults). Socialno delo, 51(6), 205-218.

Leather, P. (2000). Crumbling castles: Helping owners to repair and maintain their homes. York, UK: Joseph Rowntree Foundation.

Liu, S., \& Lapane, K. (2009). Residential modifications and decline in physical function among community-dwelling older adults. The Gerontologist, 49(3), 344-354. https://doi.org/10.1093/geront/gnp033

Maisel, N. C., Gable, S. L., \& Strachman, A. (2008). Responsive behaviour in good times and in bad. Personal Relationships, 15(3), 317-338. https:// doi.org/10.1111/j.1475-6811.2008.00201.x

Majer, S. (2015). Vsestransko učenje v tretjem življenskem obdobju (Comprehensive learning in the third period of life). Revija za univerzalno odličnost, 4(4), 194-204. 
DRUŠ. ISTRAŽ. ZAGREB GOD. 29 (2020), BR. 3, STR. 373-393

GRUM, B. KOBAL GRUM, D. THE IMPACT OF REAL...
Malačič, J. (2008). Socioekonomske posledice staranja prebivalstva gerontološki in geriatrični izzivi (Socioeconomic consequences of population aging - gerontological and geriatric challenges). Zdravniški vestnik, 77(12), 793-798.

Mandič, S. (2009). Stanovanjske razmere mladih (Housing conditions of young people). In T. Rakar \& U. Boljka (Eds.), Med otroštvom in odraslostjo, analiza položaja mladih v Sloveniji 2009 (Between childhood and adulthood, analysis of the situation of young people in Slovenia in 2009) (pp. 77-93). Ljubljana: Urad RS za mladino in Inštitut RS za socialno varstvo.

Mandič, S. (2018). Motives for home ownership: Before and after the transition. Housing Theory and Society, 35(3), 281-299. https://doi.org/10. 1080/14036096.2017.1329164

Mandič, S., \& Filipovič Hrast, M. (2018). Homeownership in multiapartment buildings: Control beyond property rights. Housing Theory and Society, 36(4), 401-425. https://doi.org/10.1080/14036096.2018. 1510853

Mandič, S., Hlebec, V., Cirman, A., Andrews, K. D., Filipovič, M., Kos, D., \& Sendi, R. (2006). Razvojno raziskovalni projekt stanovanjska anketa (RED project housing survey). Ljubljana: Univerza v Ljubljani, Fakulteta za družbene vede, Inštitut za družbene vede.

Mullins, D., Beider, H., \& Rowlands, R. (2004). Empowering communities, improving housing: Involving black and minority ethnic tenants and communities. London: Office of the Deputy Prime Minister.

Newman, S., Struyk, R., Wright, P., \& Rice, M. (1990). Overwhelming odds: Caregiving and the risk of institutionalization. The Journal of Gerontology, 45(5), 173-183. https://doi.org/10.1093/geronj/45.5.S173

Omerren, J., Rietveld, P., \& Nijkamp, P. (2000). Residential mobility and commuting. Annals of Regional Sciences, 34, 213-232. https://doi. org/10.1007/s001689900004

Parry, J., Vegeris, S., Hudson, M., Barnes, H., \& Taylor, R. (2004). Independent living in later life. Research report No 216. Available at http://campaigns.dwp.gov.uk/asd/asd5/rports2003-2004/rrep216.pdf

Ramovš, K. (2013). Nasilje nad starejšimi (Violence against the elderly). In J. Ramovš (Ed.), Staranje v Sloveniji: raziskava o potrebah, zmožnostih in stališčih nad 50 let starih prebivalcev Slovenije (Aging in Slovenia: A survey on the needs, abilities and attitudes of the population over 50 years of age in Slovenia) (pp. 342-533), Ljubljana: Inštitut Antona Trstenjaka za gerontologijo in medgeneracijsko sožitje.

Rant, M. (2013). Bivalne razmere starih ljudi (Living conditions of old people). Kakovostna starost, 16(1), 35-37.

Rohe, W. M., \& Basalo, V. (1997). Long-term effects of homeownership on the self-perception and social interaction of low-income persons. Environment and Behavior, 29(6), 793-819. https://doi.org/10.1177/ 0013916597296004

Rohe, W. M., \& Stewart, L. S. (1996). Homeownership and neighborhood stability. Housing Policy Debate, 7(1), 37-81. https://doi.org/10. 1080/10511482.1996.9521213 
DRUŠ. ISTRAŽ. ZAGREB GOD. 29 (2020), BR. 3, STR. 373-393

GRUM, B., KOBAL GRUM, D.: THE IMPACT OF REAL...
Roy, N., Bube, R., Despres, C., Freitas, A., \& Legare, F. (2018). Choosing between staying at home or moving: A systematic review of factors influencing housing decisions among frail older adults. Plos One 13(1), e0189266. https://doi.org/10.1371/journal.pone.0189266

Secker, J., Hill, R., Villeneau, L., \& Parkman, S. (2003). Promoting independence: But promoting what and how? Ageing and Society, 23(3), 375-391. https://doi.org/10.1017/S0144686X03001193

Sendi R., Černič Mali, B., Jakoš, A., \& Filipovič Hrast, M. (2003). Stanovanjske potrebe upokojencev in drugih starejših oseb (Housing needs of pensioners and other elderly people). Ljubljana: Urbanistični zavod Republike Slovenije.

SURS (2017). Število in sestava prebivalstva (Number and composition of the population). Statistični urad RS. Available at http://www.stat.si/Stat Web/Field/Index/17/104

Trček, F. (2005). Sociološka anketna raziskava, Prenova stanovanjskih sosesk v Ljubljani - Savsko naselje (Sociological survey research, Renovation of residential neighborhoods in Ljubljana - Savsko naselje). Urbani izziv, 2(16), 24-35. https://doi.org/10.5379/urbani-izziv2005-16-02-003

Uršič, M. (2005). Spreminjanje bivalne kakovosti in stanovanjska mobilnost v Ljubljani. Naraščanje socialne nestabilnosti v večjih stanovanjskih soseskah? (Changing living quality and housing mobility in Ljubljana. Rising social instability in larger residential neighborhoods?) Urbani izziv, 2(16), 36-47. https://doi.org/10.5379/urbaniizziv-2005-16-02-004

Verbrugge, L., \& Sevak, P. (2002). Use, type, and efficacy of assistance for disability. Journals of Gerontology Series B: Psychological Sciences and Social Sciences, 57(6), 366-379. https://doi.org/10.1093/geronb/57.6.S366

Walonic, D. S. (2007). Survival Statistics. StatPac, Inc., 8609.

Wiles, J. L., Leibing, A., Guberman, N., Reeve, J., \& Allem, R. E. S. (2011). The meaning of "aging in place" to older people. The Gerontologist, 5(3), 357-366. https://doi.org/10.1093/geront/gnr098

Wylde, M. A. (2008). The future of assisted living. Residents' perspectives, 2006-2026. In S. M. Golant \& J. Hyde (Eds.), The assisted living residence. A vision for the future (pp. 169-197). Baltimore, MD: The Johns Hopkins University Press.

Žmahar, A. (2013). Nepremičnina je lahko tudi breme (Real estate can also be a burden). In U. Boljka \& A. Ogrin (Eds.): Da je skupaj lažje biti sam. Zbornik prispevkov o (so) bivanju starejših (That it's easier to be alone together. Proceedings on the (co) existence of the elderly) (pp. 46-47). Ljubljana: Zveza društev upokojencev Slovenije. Available at http://www.zdus-zveza.si/docs/SVETOVALNICA-BIVANJE/ZDUS brosura_web.pdf 
DRUŠ. ISTRAŽ. ZAGREB

GOD. 29 (2020), BR. 3, STR. 373-393

GRUM, B.,

KOBAL GRUM, D.:

THE IMPACT OF REAL...

\section{Utjecaj troškova održavanja nekretnina na potencijalno preseljenje starijih osoba: slučaj Slovenije}

Bojan GRUM

Europski pravni fakultet, Nova Gorica

Darja KOBAL GRUM

Filozofski fakultet, Ljubljana

Članak razmatra kako troškovi održavanja utječu na potencijalno preseljenje starijih osoba u odgovarajuće smještajne jedinice. U Sloveniij više od 80 posto kućanstava vlasnici su svojih domova, a više od 60 posto vlasnika starije je od 65 godina. Glavni instrument kojim su se mierila njihova mišlienja bio je upitnik, a uzorak se sastojao od 471 sudionika starijeg od 65 godina. Temelini je zaključak da, unatoč visokim troškovima održavanja, slovenski sudionici istraživanja ne bi prodali svoje vlasništvo ni pod kojim uvjetima, čak ni u zamjenu za kvalitetnije životno okruženje. Njihova privrženost okruženju u kojem žive vrlo je jaka te radije riešavaju probleme održavanja nego da se sele u prikladniji dom ili okruženje. Objašnjavamo to njihovom snažnom društvenom pripadnošću mikrookruženju, jakom međugeneracijskom privrženošću i nesklonosti Slovenaca prema selidbi.

Ključne riječi: starije osobe, troškovi održavanja, preseljenje, nekretnine, demografske karakteristike, Slovenija

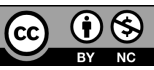

Međunarodna licenca / International License:

Imenovanje-Nekomercijalno / Attribution-NonCommercial 